\title{
Liquid Biphasic Systems for Oil-Rich Algae Bioproducts Processing
}

\author{
Hui Yi Leong ${ }^{1,+}$, Chih-Kai Chang ${ }^{2,+}$, Jun Wei Lim ${ }^{3}{ }^{\mathbb{C}}$, Pau Loke Show ${ }^{1, * \mathbb{C}}$, Dong-Qiang Lin ${ }^{4}$ \\ and Jo-Shu Chang $5,6,7, *$
}

1 Department of Chemical and Environmental Engineering, Faculty of Science and Engineering, University of Nottingham Malaysia, Jalan Broga, 43500 Semenyih, Selangor Darul Ehsan, Malaysia

2 Department of Chemical Engineering and Materials Science, Yuan Ze University, No. 135, Yuan-Tung Road, Chungli, Taoyuan 320, Taiwan

3 Department of Fundamental and Applied Sciences, Centre for Biofuel and Biochemical Research, Institute of Self-Sustainable Building, Universiti Teknologi PETRONAS, 32610 Seri Iskandar, Perak Darul Ridzuan, Malaysia

4 College of Chemical and Biological Engineering, Zhejiang University, Hangzhou 310027, China

5 Department of Chemical Engineering, National Cheng Kung University, Tainan 701, Taiwan

6 Research Center for Energy Technology and Strategy, National Cheng Kung University, Tainan 701, Taiwan

7 Research Center for Circular Economy, National Cheng Kung University, Tainan 701, Taiwan

* Correspondence: showpauloke@gmail.com or PauLoke.Show@nottingham.edu.my (P.L.S.); changjs@mail.ncku.edu.tw (J.-S.C.)

+ These authors contributed equally to this work and should be considered as co-first authors.

Received: 25 June 2019; Accepted: 16 July 2019; Published: 28 August 2019

check for updates

\begin{abstract}
Oleaginous algae are nowadays of significance for industrial biotechnology applications and for the welfare of society. Tremendous efforts have been put into the development of economically feasible and effective downstream processing techniques in algae research. Currently, Liquid Biphasic Systems (LBSs) are receiving much attention from academia and industry for their potential as green and effective downstream processing methods. This article serves to review the applications of LBSs (LBS and Liquid Biphasic Flotation System (LBFS)) in the separation, recovery and purification of algae products, as well as their basic working principles. Moreover, cell disruptive technologies incorporated into LBSs in algae research are reported. This review provides insights into the downstream processing in algae industrial biotechnology which could be beneficial for algae biorefinement.
\end{abstract}

Keywords: algae; cell disruption; downstream processing; liquid biphasic flotation system; liquid biphasic system; purification; recovery; separation

\section{Introduction}

Over the years, algae (both macro- and microalgae) have received increasing levels of attention for the downstream processing of industrial biotechnology. Macroalgae (collectively known as seaweed) have two significant functions: (i) human consumption, and (ii) the production of gelatinous compounds such as agar, alginate and carrageenan. These compounds, known as hydrocolloids or phycocolloids, play a role as food additives. On the other hand, microalgae, to some degree, play an important role in algae biorefinement [1]. Microalgae biorefinement is of growing interest worldwide; the sustainable production of valuable microalgae-derived products can be attained through biorefinery processes. These products such as biofuels, carbohydrates, proteins, lipids, polyunsaturated fatty acids (PUFAs), vitamins, antioxidants, pigments, fertilizers and natural colorants, are valuable to the society. Moreover, most are generally associated with the manufacturing of biomedical, pharmaceutical and nutraceutical products [2-9]. 
Oil-rich (oleaginous) microalgae such as Chlorella, Scenedesmus, Spirulina and Saccharina are potential biofuel feedstocks. Microalgae-derived biofuels, for example, bioethanol, biodiesel, biohydrogen, syngas and methane, are promising sources of green, renewable and sustainable energy globally [10-14]. Other than that, Chlorella and Spirulina were the first microalgae to have been commercialised as health food supplements worldwide, especially in Mexico, Taiwan and Japan. Later, $\beta$-carotene and astaxanthin from Dunaliella salina (also known as Dunaliella bardawil) and Haematoccus pluvialis, respectively, were marketed. Both $\beta$-carotene and astaxanthin are natural red pigments categorised as carotenoids, which are good for human health. Other carotenoids, such as lutein, canthaxanthin, zeaxanthin and fucoxanthin, are mostly synthesised by green algae (e.g., Scenedesmus almeriensis, Scenedesmus komareckii, Chlorella zofigiensis, Dunaliella salina, Phaeodactylum tricornutum etc.). Moreover, Crypthecodinium cohnii successfully produced docosahexaenoic acid (DHA), and the product was subsequently commercialised. DHA is a type of PUFA that can be used as a functional food to improve health by preventing non-communicable diseases as well as improving cognitive and neurological functions. Finally, Isochrysis, Nannochloropsis, Chaetoceros, Aurantiochytrium, Tetraselmis and Thalassiosira are among the PUFAs-producer microalgae $[3,8,15]$.

The high operating costs of biorefining algae mainly come from downstream processing involving various steps of recovery, isolation, purification and the polishing of target products [16]. Conventional separation and purification methods for the extraction of valuable algae products, for example, Soxhlet extraction, maceration, high pressure heating and chemicals, homogenisers and bead beating, contribute to the high production cost, impact upon the environment, and workload. These issues illustrate the need to develop new, effective, and cost-saving downstream processing techniques [3,5,8,9,13]. Liquid biphasic systems (LBSs) offer a unique, one-step procedure for downstream processing, which make them attractive for the application of industrial biotechnology [16]. LBSs including Liquid Biphasic Flotation Systems (LBFSs), i.e., a type of bubble-assisted LBS, represent green and highly-efficient separation, recovery and purification technologies for biomolecules. These systems provide a gentle working environment for the recovery of target products which can extract the products of interest without damaging other fractions $[17,18]$.

This article provides on a comprehensive review (both theoretical knowledge and empirical research) of the separation, recovery and purification of algae products by different types of LBSs (i.e., LBS and LBFS), as well as on the basic principles involved therein. In addition, different cell disruptive technologies integrated with LBSs in algae research are well-discussed (see Figure 1). To the best of the authors' knowledge, this is the first review to report on the recent trend of downstream processing technologies for algae products employing LBSs. LBSs are green, economically viable and high efficient bioseparation technologies.

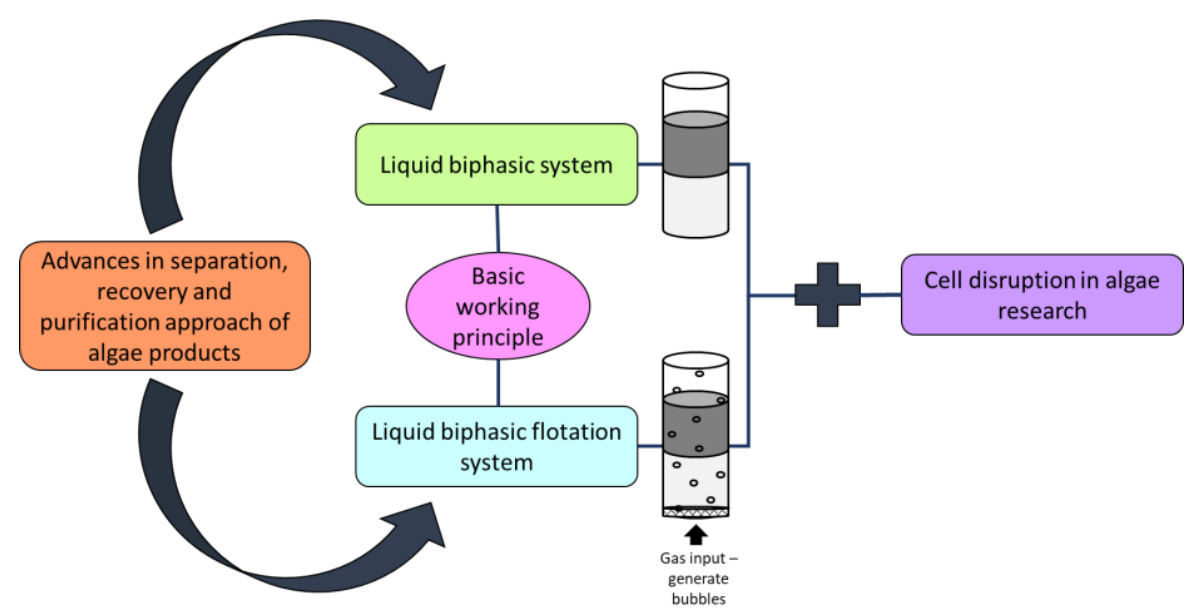

Figure 1. Schematic view illustrating the covered topics in the present review article. 


\section{Liquid Biphasic System}

The Liquid Biphasic System (LBS) is an innovative and non-conventional liquid-liquid extraction approach having extensive applications in the separation, recovery, purification and enrichment of many biotechnological and natural products such as proteins [19,20], amino acids, nucleic acids, peptides, enzymes [21-23], pigments [24,25], viruses, antibodies, cell organelles etc. It was first discovered by Martinus W. Beijerinck in 1896, when he reported a phenomenon of biphasic formation by leaving a mixture of starch and gelatine to settle by gravity. Nevertheless, no further research was conducted until its first application was introduced by Pre-Åke Albertsson in 1961 [26]. The LBS possesses various advantages, for instance, a mild and selective separation technique, ease of operation, ease and reliability of scaling-up, time-, cost- and energy-efficiency, effective and environmentally-benign, etc. Additionally, this innovative system offers a single-step procedure to separate, recover, purify and enrich target products [16-18,27-29].

The discovery of LBS was a significant breakthrough in the field of separation and purification advances, driven by the need of mild and water-rich operating conditions, as well as the use of phase-forming constituents which exhibited minimal toxicity or even environmental soundness. These conditions are very suitable for the extraction of biomolecules compared to those of conventional separation methods (e.g., solid-liquid extraction methods such as infusion, Soxhlet extraction and maceration). Conventional separation technologies are normally perceived as being less eco-friendly and inefficient, requiring harsh operating conditions and large amount of toxic organic solvents, and have resulted in lower production yields of biomolecules [18,30,31]. Polymer-based LBS, for example, the polymer/polymer and polymer/salt systems, is typical biphasic system. Later, there was a notably progression in the development of different LBS phase-forming compositions, i.e., surfactants, ionic liquids (ILs), low molecular weight alcohols and thermos separating polymers [17,23,25,32-35].

\subsection{Basic Principle of Liquid Biphasic System}

Generally, extraction with LBS involves the processes of equilibration and phase separation. Equilibration is a process in which the phase-forming compositions and partition of the target compound achieve equilibrium during the mixing of components in a biphasic system (e.g., by mass transfer mechanisms). The phase separation by gravity normally requires more time, and therefore, centrifugation at a low speed can be applied to promote a phase separation process for a shorter period. In the LBS, each phase is enriched in one or the other of the particular phase-forming constituents, and both phases consist of about $85-90 \%$ water, providing a mild working environment for biomolecules separation $[16,18,27]$.

Selective distribution of substances between two immiscible liquid phases manipulates the separation in a biphasic system. In particular, the characteristics of the substances and phase system, as well as those of both interactions, could regulate the distribution and partitioning effects in the system. A LBS has a distinctive phase diagram which defines the potential working area for a particular biphasic system under set conditions like temperature, $\mathrm{pH}$ and the concentration of phase-forming components [27]. Several factors affect the partitioning effect of target biomolecules in the LBS, including the type and concentration of phase-forming constituents, tie line length (TLL; the length of the line joining the composition of the two phases in a phase diagram), phase volume ratio $\left(V_{R}\right.$; the ratio of the two phases' volume (upper phase/lower phase)), $\mathrm{pH}$, temperature, the presence of additives such as neutral salts (e.g., sodium chloride $(\mathrm{NaCl})$ ), as well as the physicochemical properties and concentration of crude feedstock. These parameters can be determined in an optimisation study (e.g., by one-factor-at-a-time (OFAT) approach) for the LBS to achieve an optimal result $[16,17,33]$. Figure 2 shows a schematic diagram of a LBS in respect to the selective distribution of substances, for instance, the partition of the target product, unwanted substances and contaminants, as well as the biphasic separation. 


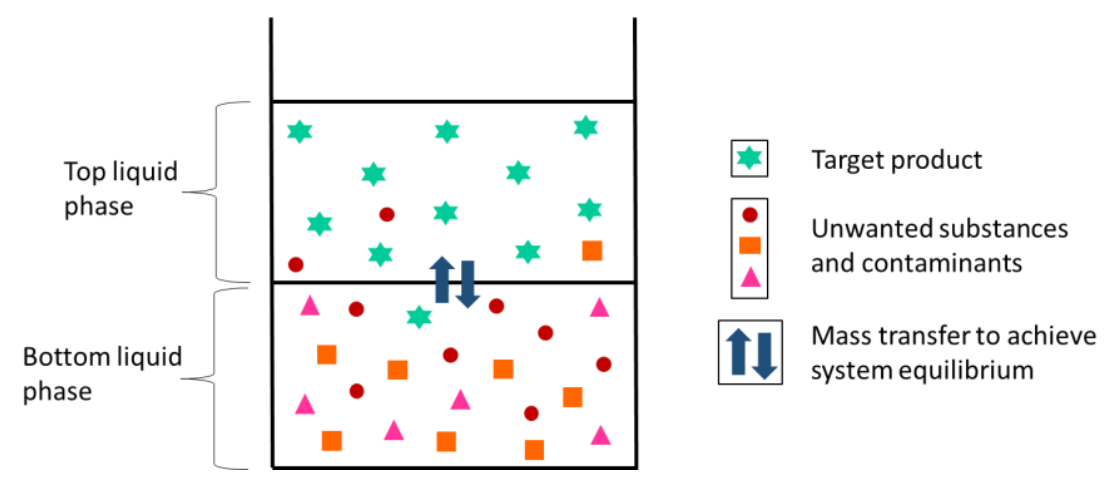

Figure 2. Schematic view illustrating a selective distribution of substances (product of interest, unwanted substances and contaminants) and phase separation in LBS.

\subsection{Application of Liquid Biphasic System for the Extraction of Algae Products}

In 2005, Benavides and Rito-Palomares [36] reported that a LBS composed of polyethylene glycol (PEG) and potassium phosphate represented an effective extraction system for the primary recovery of coloured proteins from microalgae in a single stage. In their study, multiple stages of a PEG/potassium phosphate-based LBS were also conducted; however, no significance augmentation in protein purity (a slight increment of $0.1-0.3 \%$; single-stage LBS is enough to purify the proteins) was observed, whereas there was a great reduction in the protein yield (a drop of 24-33\%) after three consecutive runs. This could be explained by the denaturation of the protein after the long extraction time. Under optimised conditions (PEG 1450, $\mathrm{V}_{\mathrm{R}}=0.3$, TLL $=34 \%(w / w)$ and $\left.\mathrm{pH}=7.0\right), \mathrm{C}$-phycocyanin (CPC) from Spirulina maxima was recovered with a purity of 2.1 and a yield of $98 \%(w / w)$. For the recovery of B-phycoerythrin (BPE) from Porphyridium cruentum, PEG 1000/potassium phosphate-based LBS with $\mathrm{V}_{\mathrm{R}}$ of 1.0, TLL of $50 \%(w / w)$ and $\mathrm{pH} 7.0$, produced a purity of 2.8 and a yield of $82 \%(w / w)$. Compared to the protein purity of the crude extract (0.7), both the purities of CPC and BPE recovered using the optimised LBS were significantly increased by 3 and 4 times, respectively, and the target products were mostly concentrated in the PEG-rich top phase. CPC (i.e., a blue-coloured protein) and BPE (i.e., a red-coloured protein) are phycobiliproteins that have great commercial significance in industrial applications, owing to their good nutritional and functional properties [36,37].

Later, Desai et al. [38] conducted the extraction of pure Rubisco (Ribulose-1, 5-biphosphate carboxylase oxygenase; purity of $\sim 80 \%$ ) using Iolilyte 221PG/sodium potassium phosphate $\left(\mathrm{Na}_{2} \mathrm{HPO}_{4}\right)$ and PEG/potassium citrate $\left(\mathrm{K}_{3} \mathrm{C}_{6} \mathrm{H}_{5} \mathrm{O}_{7}\right)$-based LBS based on the Design of Experiments approach. Rubisco accounts for $50 \%$ of the total proteins found in microalgae, and it can be used in food processing. The Iolilyte 221PG used was a type of $\mathrm{IL}$, and it is an eco-benign compound with numerous advantageous characteristics such as low vapour pressure, good solubility and solvating capacity, as well as high thermal and chemical stability that ensure a greener, milder and higher efficiency extraction process for the biomolecules [39]. The target product (Rubisco) was mainly partitioned to the IL- or PEG-rich top phase. Compared to the PEG/ $\mathrm{K}_{3} \mathrm{C}_{6} \mathrm{H}_{5} \mathrm{O}_{7}$-based LBS, Iolilyte 221PG/Na $\mathrm{Na}_{2} \mathrm{HPO}_{4}$-based LBS showed a 3 to 4 times higher partition coefficient of Rubisco, and hence, IL/salt system was shown to be a better LBS in the extraction of Rubisco [38].

Moreover, another IL-based system (Iolilyte 221PG/potassium citrate $\left(\mathrm{K}_{3} \mathrm{C}_{6} \mathrm{H}_{5} \mathrm{O}_{7}\right)$-based LBS) was reported on the fractionation of proteins and carbohydrates from green microalgae Neochloris oleoabundans and Tetraselmis suecica, and analysed using a Non-Random Two Liquids (NRTL) model. The proteins and sugars were selectively partitioned in the IL-rich top and salt-rich bottom phase, respectively, in the LBS. The results inferred that simultaneous extraction could be achieved by using such a LBS [39]. Other than that, study of the isolation and extraction of CPC from microalgae Spirulina platensis by imidazolium ILs/potassium salts-based LBS were undertaken. Under optimised conditions (C8MIM-Br, dipotassium phosphate $\left(\mathrm{K}_{2} \mathrm{HPO}_{4}\right), 0.5 \mathrm{~mL}$ of $1 \%$ disrupted algae, $\mathrm{pH}=7.0$, temperature $=308 \mathrm{~K}$ and $\left.\mathrm{V}_{\mathrm{R}}=2.7\right)$, the separation factor, partition coefficient and extraction efficiency 
of CPC were 5.8, 36.6 and 99\%, respectively; CPC was mostly in the IL-rich top phase. The investigated ILs in the LBS regarding the extraction efficiency of CPC from Spirulina platensis was followed by an order of 1-octyl-3-methylimidazolium bromide (C8MIM-Br) $>$ 1-hexyl-3-methylimidazolium bromide (C6MIM-Br) > 1-butyl-3-methylimidazolium bromide (C4MIM-Br) [37].

Additionally, an organic solvent-based LBS was widely used in algae research [40-43]. For organic solvent systems, the products of interest can easily be recovered by the removal of organic solvents (e.g., hexane, alcohol etc.) through evaporation, crystallisation or distillation. This system also possesses several benefits, for instance, it is of lower toxicity to the environment, relatively inexpensive, faster segregation of the two phases and scalability [32]. In this context, Najafabadi et al. [41] studied the use of an organic solvent-based LBS to purify the extracted lipids from microalgae Chlorella vulgaris. The biphasic system composed of hexane and water could successfully separate the fatty acids and contaminants. The fatty acids mostly distributed in the organic phase, while the contaminants generally remained in the liquid phase [41]. Moreover, an alcohol/salt-based LBS composed of ethanol and potassium phosphate was reported to provide the optimum partition of fucoxanthin from microalgae in the ethanol-rich top phase. The highest recovery and purity of fucoxanthin from the methanolic crude extracts of Phaeodactylum tricornutum (95.36\% and $66.01 \%$, respectively) and Isochrysis galbana $\left(89.18 \%\right.$ and $78.74 \%$, respectively) were achieved in the optimised LBS with (TLL of $50 \%(w / w), V_{R}$ of 1 ) and (TLL of $60 \%(w / w), V_{R}$ of 3), respectively [40].

A study by Phong et al. [42] reported that a recovery of microalgae proteins from Chlorella sorokiniana using methanol/potassium salt-based LBS. The LBS with the optimised conditions $(20 \%(w / w)$ and $30 \%(w / w)$ of methanol and tripotassium phosphate $\left(\mathrm{K}_{3} \mathrm{PO}_{4}\right)$, respectively, with supplementation of $3 \%(w / w)$ of $\mathrm{NaCl})$, resulted in the highest yield and partition coefficient of proteins, with values of $84.23 \%$ and 7.28 , respectively. This study also revealed the possibility of 100 -fold up-scaling of LBS, owing to no significant differences in the partition coefficient and yield of proteins between the smalland large-scale system [42]. Besides that, a 2-propanol/ammonium sulphate $\left(\left(\mathrm{NH}_{4}\right)_{2} \mathrm{SO}_{4}\right)$-based LBS with optimised conditions represented a sustainable and effective method for the recovery $(>75 \%)$ and purification (1.5-2.5 of purification factor) of phlorotannin from brown macroalgae (Padina australis and Sargassum binderi) [43]. These studies successfully demonstrated the recyclability of phase-forming compounds in LBS [42,43].

In order to further develop the LBS as a more efficient separation technique, a vortex fluidic device (VFD) was incorporated (VFD-LBS) in a study carried out by Luo et al. [44]. The CPC purification from Spirulina maxima using VFD-intensified PEG 4000/potassium phosphate-based LBS continuous flow processing technique was investigated. This new integrated biphasic system was of significance, in that an increment of 1.18 -fold and $22 \%$ in the purity and yield of CPC, respectively, as well as high effectiveness in the phase demixing, were achieved, compared to the normal (or standard) LBS approaches (performed within this study). Also, multi-stages of VFD-LBS further enhanced the purity of CPC by 6-fold higher compared to the crude extract [44]. In contrast, multi-stages of a PEG/potassium phosphate-based LBS reported by Benavides and Rito-Palomares [36] showed no significant augmentation in the protein purity, which was in contrast to the results obtained in Luo et al. [44]; the reason for this contradiction could be the different biphasic systems used in both studies.

Furthermore, in 2019, Mittal and coworkers studied the extraction of R-phycoerythrin (RPE) (i.e., a type of phycobiliprotein) from Gelidium pusillum, a marine macroalgae. A normal LBS was compared to an integrated LBS with precipitation for the extraction efficiency of RPE. The integrated LBS with precipitation showed a better yield and purity of RPE (72\% (w/w), 0.74 , respectively); 9.25-fold enhancement on the extraction of RPE compared to the normal LBS. The precipitation process introduced in this experiment (i.e., precipitation by $70 \%$ ammonium sulphate $\left.\left(\left(\mathrm{NH}_{4}\right)_{2} \mathrm{SO}_{4}\right)\right)$ was to pre-purify the crude algae feedstock. The optimised conditions in the integrated LBS with precipitation were the use of PEG 1450 and potassium phosphate, TLL of $12.26 \%(w / w), \mathrm{V}_{\mathrm{R}}$ of 0.29 and $\mathrm{pH} 6$ [45]. 
To conclude this section, LBSs are of attracting more attention as substitutes for conventional separation, recovery and purification methods in algae research, owing to their advantages. Modified LBSs are nonetheless necessary to attain better biomolecule separation performance.

\section{Liquid Biphasic Flotation System}

In 2017, P. L. Show's research group introduced a Liquid Biphasic Flotation System (LBFS) that was modified from an aqueous two-phase flotation (ATPF) as a separation, recovery, purification and enrichment method for biomolecules; ATPF was first introduced by Bi and co-workers in 2009 [46]. Thereafter, extensive studies on the application of LBFS were conducted until the present [47-55]. For example, extractions of betacyanins from red-purple pitaya using normal and electric-assisted alcohol/salt-based LBFS were conducted by Leong and co-workers [52,53]. Also, the recovery of proteins $[47,50,51,54,55]$ and enzymes $[48,49]$ from bio-based feedstocks was successfully accomplished by normal and modified LBFSs. The LBFS is a modified LBS; sometimes known as a bubble-assisted LBS, it is an integration approach of a LBS and solvent sublation (SS) technique. Therefore, LBFS presents the benefits of LBSs and SS, and are a very promising tool for the separation, recovery and purification of labile biological products from numerous sources. Besides that, the LBFS represents a highly biocompatible technique, has a low environmental impact and high enrichment factor, as well as being economical and simple to use [17].

\subsection{Basic Principle of Liquid Biphasic Flotation System}

The LBFS is an innovative separation technology that integrates the working mechanisms of the LBS with the mass transfer mode of the SS method (i.e., a non-foaming bubble adsorptive separation); thus, it is coined as a bubble-assisted LBS. In LBFS, the mass transfer mode of SS is applied to facilitate the mass transfer of biological compounds in liquid bi-phases. SS was formerly presented by Sebba, who studied the use of a flotation technique for the enrichment of various inorganic ions from aqueous solutions [56,57]. The recovery of hydrophobic or surface-active molecules was of significance, as reported by the utilisation of the SS approach. SS effectively concentrates the products of interest through the adsorption on the bubble surface to the top layer, followed by releasing the products via a bubble rupturing process. The complete mass transfer mechanisms (e.g., mass transfer by molecular diffusion and water droplets) and working principles of SS were recently reviewed [17].

Figure 3 shows a biomolecule separation process by LBFS. Generally, in LBFS, a gas stream (normally inert gases) is introduced to a customised flotation glass column equipped with a sintered glass disk, in which the column contains two immiscible liquid phases. The sintered glass disk is used to generate a uniform bubbling effect. In particular, a sintered glass disk made of G4 porosity (5-10 $\mu \mathrm{m}$ pore size) is preferred over the other pore sizes (such as G3: 20-30 $\mu \mathrm{m}, \mathrm{G} 5: 1-4 \mu \mathrm{m}$ etc.), due to higher separation effectiveness of biomaterials [58,59]. The crude feedstock containing the target compound is first mixed with the bottom phase before moving into the flotation column, followed by the addition of top phase. The bubbles that are generated by a gas input in the flotation column carry target products (hydrophobic or surface-active molecules) which have risen through the bottom to the top liquid phase, in which their actions are governed by the mass transfer mode of SS. There are several mass transfer mechanisms in LBFS: (i) by gas bubbles, (ii) by molecular diffusion and (iii) by water droplets. The completeness of these processes ensures that the system reaches equilibrium as well as attaining better separation performance. Moreover, the separation efficiency of the LBFS is dependent on several operating parameters, for instance, type, concentration, volume and molecular weight of phase-forming constituents, size of gas bubble, gas flow rate, flotation time, $\mathrm{pH}$, as well as concentration and physicochemical properties of crude feedstock [17,47,48]. 


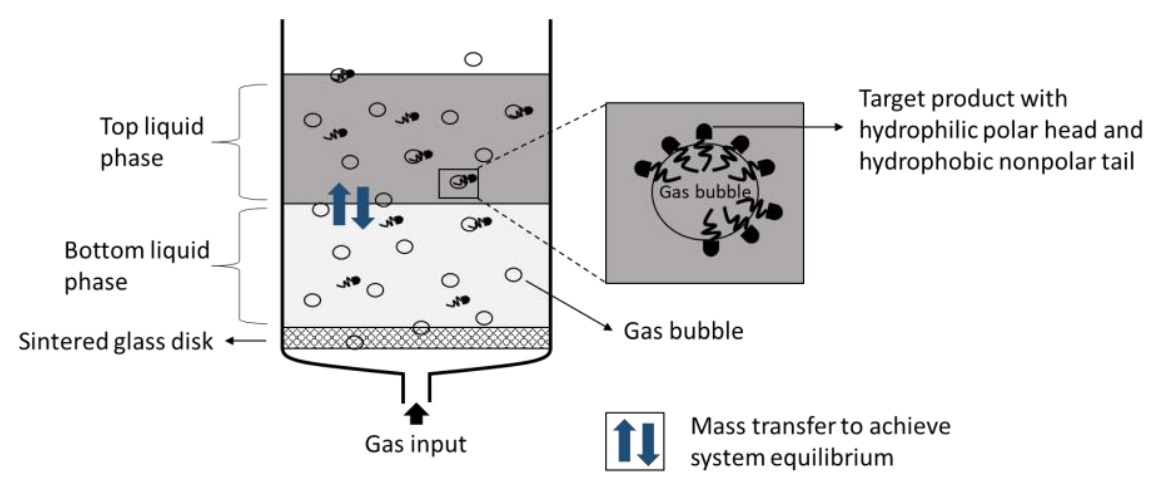

Figure 3. Schematic view illustrating partition of product of interest in LBFS.

\subsection{Application of Liquid Biphasic Flotation System for the Extraction of Algae Products}

Chew et al. [55] reported that the LBFS represents an efficient, rapid and simple approach for the recovery and purification of CPC from dried Spirulina platensis. The optimised PEG/salt system attained the highest recovery $(90.4 \%)$ and purification (3.49-fold) of microalgae. On the other hand, Phong and co-workers [47] utilised an optimised 2-propanol/ammonium sulphate $\left(\left(\mathrm{NH}_{4}\right)_{2} \mathrm{SO}_{4}\right)$-based LBFS to recover proteins from wet biomass of microalgae Chlorella sorokiniana CY-1. The optimised system (2-propanol $=60 \%(v / v),\left(\mathrm{NH}_{4}\right)_{2} \mathrm{SO}_{4}=250 \mathrm{~g} / \mathrm{L}, \mathrm{V}_{\mathrm{R}}=1.0$, crude concentration $=20 \mathrm{~g} / \mathrm{L}$, air flow rate $=4 \mathrm{~mm}^{3} / \mathrm{min}$ and flotation time $=10 \mathrm{~min}$ ) successfully attained the highest amount of proteins. The recyclability of phase-forming components was achieved (both on small and large scales), and the use of recycled alcohol for up to three cycles in the large scale $(400 \mathrm{~mL})$ produced $88.86 \%$ of the proteins with a separation efficiency of $97.44 \%$. Similarly, Phong et al. [42] and Chia et al. [43] also reported this attractive feature of recyclability of the phase-forming compounds in the biphasic system. In addition, this research estimated a total protein content of 33.70\% in Chlorella sorokiniana CY-1, which was calculated by considering a nitrogen-to-protein (NTP) conversion factor of 4.78 [47].

Later, Sankaran and co-workers [50] inventively integrated LBFS with ultrasonication for the extraction of proteins from a wet biomass of microalgae Chlorella vulgaris FSP-E. This study utilised the novel concept of the sugaring-out effect, instead of the typical salting-out effect in LBSs, i.e., an acetonitrile (ACN)/sugar-based LBFS. The ultrasonication process (by ultrasonic probe) was applied to disrupt the algae cell wall in order to release the intracellular proteins into the environment of the extracting solution. The integration process of ultrasonication and the LBFS was shown to have a higher separation efficiency and yield of proteins compared to others (i.e., LBFS without ultrasonication and ultrasonication without LBFS). The integration process of ultrasonication and ACN/sugar-based LBFS was optimised as follows: microalgae biomass concentration $=0.6 \%(w / w)$, sugar $=$ glucose with concentration of $200 \mathrm{~g} / \mathrm{L}$, concentration of $\mathrm{ACN}=100 \%$, position of the probe = interface (between top and bottom phase) of the biphasic system, sonication/flotation (a simultaneous process) time with ultrasonic pulse mode (ultrasound of $20 \%$ amplitude of a $200 \mathrm{~W}$ maximal power) $=5 \mathrm{~min}$ of $5 \mathrm{~s}$ ON/10 $\mathrm{s}$ OFF pulse mode and air flow rate $=100 \mathrm{cc} / \mathrm{min}$. This achieved a better performance by showing the highest separation efficiency and yield of proteins, with values of $86.38 \%$ and $93.33 \%$, respectively. This study successfully developed a simultaneous process of cell disruption and protein extraction by integrating sugaring-out-based LBFSs with ultrasonication for effective protein extraction, as well as promoting the reliability of scalable feature of this integrated system (separation efficiency and yield of proteins in large scale were $85.25 \%$ and $92.24 \%$, respectively); lab scale: $300 \mathrm{~mL}$ including $150 \mathrm{~mL}$ of $\mathrm{ACN}$ and 150 of $\mathrm{mL}$ sugar solution, large scale: 5 times of the lab scale [50].

Likewise, a recent study by Chia et al. also reported the use of a simultaneous process of cell disruption and protein extraction using integrated ACN/sugar-based LBFS with ultrasonication for the isolation of microalgae proteins [54]. This study utilised a different microalgae strain, Chlorella sorokiniana CY-1, instead of Chlorella vulgaris FSP-E [50]. Besides that, a slight difference in the optimised conditions, i.e., the use of a lower biomass concentration of $0.25 \mathrm{~g}($ or $0.083 \%(w / w))$ and a different 
volume ratio of top against bottom phase (1.25:1) with other conditions in the system seem to be similar in the study reported by Sankaran and co-workers [50]. The optimised integration process of sugaring-out-assisted LBFS and ultrasonication demonstrated the efficient proteins separation from Chlorella sorokiniana CY-1, with the highest proteins yield of $80 \%$ and a separation efficiency of $49 \%$ [54]. Compared to the results reported by Phong et al. [47], who studied the proteins recovery from Chlorella sorokiniana CY-1 with alcohol-salt/based LBFS, the protein separation efficiency in the current study is reduced, but the protein yields are comparable.

Moreover, a modified LBFS which incorporated an electric system (namely liquid biphasic electric flotation system (LBEFS)) for the extraction of proteins from Chlorella sorokiniana CY-1 was reported [51]. An electricity treatment, instead of the ultrasonication process, to perform cell disruption was used. Bubbles are created during the electricity treatment, and the disrupted cell adsorbed on the bubble surface (bubbles from both the electricity treatment and LBFS), which would flow up to the upper phase in the biphasic system. An alcohol/salt-based LBEFS with $60 \%(v / v)$ of 1-propanol, $250 \mathrm{~g} / \mathrm{L}$ of dipotassium phosphate $\left(\mathrm{K}_{2} \mathrm{HPO}_{4}\right)$, wet biomass of $0.1 \mathrm{~g}$, flotation/electricity treatment (a simultaneous process) time of $10 \mathrm{~min}$, air flow rate of $150 \mathrm{cc} / \mathrm{min}$, voltage of $20 \mathrm{~V}$ and position of electrodes located on the top phase represented the optimised LBEFS, and provided a better protein recovery performance. The highest separation efficiency and protein recovery were noted at $173.0870 \%$ and $23.4106 \%$, respectively. In the present study, LBEFS demonstrated better performance compared to standard LBFS for the protein recovery [51]. Remarkably, the protein separation efficiency from Chlorella sorokiniana CY-1 is significantly higher in LBEFS compared to those reported in the aforementioned studies [47,54]; however, these studies showed higher protein yields. This could be explained by the batch variation in the microalgae cultivation process. Collectively, LBSs (including LBFS) are a promising extraction approach for algae products. The application of numerous types of LBSs (i.e., LBS and LBFS) in the extraction of algae products are summarised in Table 1. 
Table 1. Extraction of algae products by means of various types of LBS and LBFS.

\begin{tabular}{|c|c|c|c|c|c|}
\hline Type of LBS/LBFS & Phase-forming Constituents & Integration Process & Product of Interest & Algae Crude Feedstock & Reference \\
\hline \multirow{3}{*}{ Polymer-based LBS } & $\begin{array}{l}\text { Polyethylene glycol (PEG) } \\
\text { 1450/potassium phosphate salt }\end{array}$ & NA & C-phycocyanin & Spirulina maxima & \multirow[t]{2}{*}{ [36] } \\
\hline & PEG 1000/potassium phosphate salt & NA & B-phycoerythrin & Porphyridium cruentum & \\
\hline & PEG/potassium phosphate salt & $\begin{array}{l}\text { Ammonium sulphate } \\
\text { precipitation } \\
\text { (pre-purification) }\end{array}$ & R-phycoerythrin & Gelidium pusillum & [45] \\
\hline $\begin{array}{l}\text { Vortex fluidic device (VFD) } \\
\text { assisted polymer-based LBS }\end{array}$ & PEG 4000/potassium phosphate salt & NA & C-phycocyanin & Spirulina maxima & [44] \\
\hline \multirow{2}{*}{ Ionic liquids (ILs)-based LBS } & Iolilyte 221PG/potassium citrate salt & NA & $\begin{array}{l}\text { Proteins and } \\
\text { carbohydrates }\end{array}$ & $\begin{array}{l}\text { Neochloris oleoabundans } \\
\text { and Tetraselmis suecica }\end{array}$ & [39] \\
\hline & $\begin{array}{l}\text { 1-octyl-3-methylimidazolium bromide } \\
\text { (C8MIM-Br)/dipotassium phosphate salt }\end{array}$ & NA & C-phycocyanin & Spirulina platensis & [37] \\
\hline \multirow{4}{*}{ Organic solvent-based LBS } & Hexane/water & NA & Fatty acids & Chlorella vulgaris & [41] \\
\hline & Ethanol/potassium phosphate salt & NA & Fucoxanthin & $\begin{array}{l}\text { Phaeodactylum tricornutum } \\
\text { and Isochrysis galbana }\end{array}$ & [40] \\
\hline & Methanol/tripotassium phosphate salt & $\begin{array}{l}\text { Ultrasonication } \\
\text { (pre cell disruption) }\end{array}$ & Proteins & Chlorella sorokiniana & [42] \\
\hline & 2-propanol/ammonium sulphate salt & NA & Phlorotannin & $\begin{array}{l}\text { Padina australis and } \\
\text { Sargassum binderi }\end{array}$ & [43] \\
\hline Polymer-based LBFS & PEG 4000/potassium phosphate salt & $\begin{array}{l}\text { Ultrasonication } \\
\text { (pre cell disruption) }\end{array}$ & C-phycocyanin & Spirulina platensis & [55] \\
\hline \multirow{2}{*}{ Organic solvent-based LBFS } & 2-propanol/ammonium sulphate salt & $\begin{array}{l}\text { Ultrasonication } \\
\text { (pre cell disruption) }\end{array}$ & Proteins & Chlorella sorokiniana CY-1 & [47] \\
\hline & 1-propanol/dipotassium phosphate salt & $\begin{array}{l}\text { Simultaneous process with } \\
\text { electricity treatment }\end{array}$ & Proteins & Chlorella sorokiniana CY-1 & [51] \\
\hline \multirow{2}{*}{$\begin{array}{l}\text { Sugaring-out assisted organic } \\
\text { solvent-based LBFS }\end{array}$} & Acetonitrile $(\mathrm{ACN}) /$ glucose & $\begin{array}{l}\text { Simultaneous process with } \\
\text { ultrasonication }\end{array}$ & Proteins & Chlorella vulgaris FSP-E & [50] \\
\hline & ACN/glucose & $\begin{array}{l}\text { Simultaneous process with } \\
\text { ultrasonication }\end{array}$ & Proteins & Chlorella sorokiniana CY-1 & [54] \\
\hline
\end{tabular}

NA: Not available. 


\section{Cell Disruption Integrated with Liquid Biphasic Systems in Algae Research}

A mild cell disruption is a prerequisite procedure in the extraction of algae products to ensure a completeness of the extraction process which maintains the native properties of the compound. It is applied to disrupt the cell wall and membrane of the biomolecules in order to increase the cell membrane permeability in releasing intracellular compounds. Cell disruptive technologies can be divided into three categories: the physical approach (e.g., electricity treatment such as pulsed electric field (PEF), microwave etc.), mechanical approach (e.g., high pressure homogenisation, bead milling, ultrasonication etc.) and chemical approach (e.g., acid or alkali treatment, enzymatic reaction etc.). Among them, the physical approach is the best choice, owing to its environmental soundness and reduced energy-consumption, compared to the other available techniques $[8,9,60-62]$.

Currently, LBSs can be used not only to separate, recover and purify algae products in a single step, but can also be incorporated with cell disruptive technologies for the purpose of biomolecule extraction. The integration process is of practical and economic importance in downstream processing. It is a costand energy-efficient method which offers rapid processing with lower chance of product denaturation or modification and which offers higher yields and better molecular quality of the resulting products. For instance, Phong and coworkers integrated ultrasonication with a LBS [42] and LBFS [47], as a pre cell disruption process in order to enhance the protein extraction efficiency from microalgae Chlorella sorokiniana. Also, Chew et al. [55] applied ultrasonication as a pre cell disruption approach in the study of CPC purifying from Spirulina platensis using LBFS. Moreover, a simultaneous process of cell disruption and protein extraction from microalgae using integrated LBFS with ultrasonication $[50,54]$ and electricity treatment [51] were reported, and remarkably, a better performance of the protein separation was observed.

To seek further enhancement of biomolecule separation methods in algae industrial biotechnology, more integration processes or modifications to LBSs could be widely implemented. In addition, a techno-economic scenario study developing a single processing unit comprising harvesting, cell disruption and extraction of target products by LBSs in algae research is a future prospect. Algae cell harvesting is normally performed in numerous ways such as centrifugation, flocculation or sedimentation, filtration, flotation, magnetic separation, electrolysis, ultrasound and immobilisation $[9,63]$. However, more work is required to attain better ways of algae cell harvesting with reduced cost and energy consumption, as well as optimal yield and quality of the algae products. This is to circumvent the drawbacks of the existing harvesting techniques such as high energy input and cost. A single processing unit that consists of harvesting, cell disruption and the extraction of algae products is believed to be beneficial to algae biorefinement, owing to its techno-economic feasibility.

\section{Prospective and Challenges}

LBSs are of great potential in separation, recovery and purification technologies for biomolecules owing to their promising biomolecule extraction performance. However, knowledge on partitioning effects of the product of interest in LBSs is scarce. Therefore, intensive research of LBSs should be conducted, for example, kinetics and thermodynamics studies on the partitioning effects in the LBSs, as well as a model designing study related to the application of LBSs ought to be undertaken. In addition, modification to LBSs is needed to accomplish better biomolecule separation performance compared to conventional LBSs.

The phase-forming constituents in LBSs can not only be recycled, but also applied to other purposes, e.g., example, the use of unwanted phase-forming components for microorganism cultivation [2]. Leong and co-workers studied microalgae Aurantiochytrium limacinum SR21 cultivation using a salt-rich waste feedstock obtained from LBS, and a higher lipid accumulation and DHA content was noted compared to those of cultivation with original culture medium. It is a good practice to manage waste. The waste refinery process is a practical and sustainable method to promote a greener environment.

Moreover, investigation of cancer research using algae products can be carried out. Literature studies report that algae extracts have shown numerous biological activities including anticancer, 
anti-inflammatory and anti-angiogenic properties, which represent promising agents to prevent chronic diseases like cancer. In particular, they showed a promising chemo preventive action against carcinogenesis. Also, algae cultivation is easy and requires minimal investment $[3,64,65]$. The development of cancer research with algae extracts would be undeniably advantageous to society and to the medical field.

\section{Conclusions}

This article provides insights into the recent separation, recovery and purification technologies in algae industrial biotechnologies. In particular, LBSs (LBS and LBFS) are practical methods for the extraction of algae products. Modification on the LBSs further enhances the extraction performance, as well as attaining greater innovation compared to conventional LBSs. The downstream processing of algae research should be continuously developed in order to achieve techno-economically feasible extraction methods. Moreover, cancer research with algae products should be implemented to benefit the medical field and society.

Author Contributions: Conceptualization, H.Y.L., C.-K.C., P.L.S. and J.-S.C.; writing-original draft preparation, H.Y.L. and C.-K.C.; writing-review and editing, H.Y.L., C.-K.C. and D.-Q.L.; visualization, H.Y.L. and C.-K.C.; project administration, J.W.L., P.L.S. and J.-S.C.; funding acquisition, J.W.L.

Funding: This research was funded by Universiti Teknologi PETRONAS, grant number YUTP-FRG (0153AA-E48) and Ministry of Education Malaysia under HICoE.

Conflicts of Interest: The authors declare no conflict of interest.

$\begin{array}{ll}\text { Abbreviations } \\ \text { ACN } & \text { acetonitrile } \\ \text { ATPF } & \text { aqueous two-phase flotation } \\ \text { BPE } & \text { B-phycoerythrin } \\ \text { CPC } & \text { C-phycocyanin } \\ \text { IL } & \text { ionic liquid } \\ \text { LBEFS } & \text { liquid biphasic electric flotation system } \\ \text { LBFS } & \text { liquid biphasic flotation system } \\ \text { LBS } & \text { liquid biphasic system } \\ \text { NRTL } & \text { Non-Random Two Liquids } \\ \text { NTP } & \text { nitrogen-to-protein } \\ \text { OFAT } & \text { one-factor-at-a-time } \\ \text { PEF } & \text { pulsed electric field } \\ \text { PEG } & \text { polyethylene glycol } \\ \text { PUFA } & \text { polyunsaturated fatty acid } \\ \text { RPE } & \text { R-phycoerythrin } \\ \text { SS } & \text { solvent sublation } \\ \text { TLL } & \text { tie line length } \\ \text { VFD } & \text { vortex fluidic device } \\ \text { V } & \text { phase volume ratio } \\ & \end{array}$

\section{References}

1. Kleinegris, D.M.M.; Janssen, M.; Brandenburg, W.A.; Wijffels, R.H. Two-phase systems: Potential for in situ extraction of microalgal products. Biotechnol. Adv. 2011, 29, 502-507. [CrossRef]

2. Leong, H.Y.; Su, C.-A.; Lee, B.-S.; Lan, J.C.-W.; Law, C.L.; Chang, J.-S.; Show, P.L. Development of Aurantiochytrium limacinum SR21 cultivation using salt-rich waste feedstock for docosahexaenoic acid production and application of natural colourant in food product. Bioresour. Technol. 2019, 271, 30-36. [CrossRef] [PubMed]

3. Chew, K.W.; Yap, J.Y.; Show, P.L.; Suan, N.H.; Juan, J.C.; Ling, T.C.; Lee, D.-J.; Chang, J.-S. Microalgae biorefinery: High value products perspectives. Bioresour. Technol. 2017, 229, 53-62. [CrossRef] [PubMed] 
4. Trivedi, J.; Aila, M.; Bangwal, D.P.; Kaul, S.; Garg, M.O. Algae based biorefinery—How to make sense? Renew. Sustain. Energy Rev. 2015, 47, 295-307. [CrossRef]

5. Yen, H.-W.; Hu, I.C.; Chen, C.-Y.; Ho, S.-H.; Lee, D.-J.; Chang, J.-S. Microalgae-based biorefinery - From biofuels to natural products. Bioresour. Technol. 2013, 135, 166-174. [CrossRef] [PubMed]

6. Venkata Mohan, S.; Nikhil, G.N.; Chiranjeevi, P.; Nagendranatha Reddy, C.; Rohit, M.V.; Kumar, A.N.; Sarkar, O. Waste biorefinery models towards sustainable circular bioeconomy: Critical review and future perspectives. Bioresour. Technol. 2016, 215, 2-12. [CrossRef] [PubMed]

7. Ansari, F.A.; Shriwastav, A.; Gupta, S.K.; Rawat, I.; Guldhe, A.; Bux, F. Lipid extracted algae as a source for protein and reduced sugar: A step closer to the biorefinery. Bioresour. Technol. 2015, 179, 559-564. [CrossRef] [PubMed]

8. $\quad$ t Lam, G.P.; Vermuë, M.H.; Eppink, M.H.M.; Wijffels, R.H.; van den Berg, C. Multi-product microalgae biorefineries: From concept towards reality. Trends Biotechnol. 2018, 36, 216-227. [CrossRef]

9. Kim, J.; Yoo, G.; Lee, H.; Lim, J.; Kim, K.; Kim, C.W.; Park, M.S.; Yang, J.-W. Methods of downstream processing for the production of biodiesel from microalgae. Biotechnol. Adv. 2013, 31, 862-876. [CrossRef]

10. Tan, C.H.; Show, P.L.; Chang, J.-S.; Ling, T.C.; Lan, J.C.-W. Novel approaches of producing bioenergies from microalgae: A recent review. Biotechnol. Adv. 2015, 33, 1219-1227. [CrossRef]

11. Yoshida, M.; Tanabe, Y.; Yonezawa, N.; Watanabe, M.M. Energy innovation potential of oleaginous microalgae. Biofuels 2012, 3, 761-781. [CrossRef]

12. Malcata, F.X. Microalgae and biofuels: A promising partnership? Trends Biotechnol. 2011, 29, 542-549. [CrossRef] [PubMed]

13. Cooney, M.; Young, G.; Nagle, N. Extraction of bio-oils from microalgae. Sep. Purif. Rev. 2009, 38, $291-325$. [CrossRef]

14. Chisti, Y. Biodiesel from microalgae. Biotechnol. Adv. 2007, 25, 294-306. [CrossRef] [PubMed]

15. Borowitzka, M.A. High-value products from microalgae-their development and commercialisation. J. Appl. Phycol. 2013, 25, 743-756. [CrossRef]

16. Raja, S.; Murty, V.R.; Thivaharan, V.; Rajasekar, V.; Ramesh, V. Aqueous two phase systems for the recovery of biomolecules-A review. Sci. Technol. 2011, 1,7-16. [CrossRef]

17. Lee, S.Y.; Khoiroh, I.; Ling, T.C.; Show, P.L. Aqueous two-phase flotation for the recovery of biomolecules. Sep. Purif. Rev. 2016, 45, 81-92. [CrossRef]

18. Iqbal, M.; Tao, Y.; Xie, S.; Zhu, Y.; Chen, D.; Wang, X.; Huang, L.; Peng, D.; Sattar, A.; Shabbir, M.A.B. Aqueous two-phase system (ATPS): An overview and advances in its applications. Biol. Proced. Online 2016, 18, 18. [CrossRef]

19. Khan, B.M.; Cheong, K.-L.; Liu, Y. ATPS: “Aqueous two-phase system" as the "answer to protein separation" for protein-processing food industry. Crit. Rev. Food Sci. Nutr. 2018. [CrossRef]

20. Lin, Y.K.; Ooi, C.W.; Tan, J.S.; Show, P.L.; Ariff, A.; Ling, T.C. Recovery of human interferon alpha-2b from recombinant Escherichia coli using alcohol/salt-based aqueous two-phase systems. Sep. Purif. Technol. 2013, 120, 362-366. [CrossRef]

21. Naganagouda, K.; Mulimani, V.H. Aqueous two-phase extraction (ATPE): An attractive and economically viable technology for downstream processing of Aspergillus oryzae $\alpha$-galactosidase. Process Biochem. 2008, 43, 1293-1299. [CrossRef]

22. Show, P.L.; Tan, C.P.; Anuar, M.S.; Ariff, A.; Yusof, Y.A.; Chen, S.K.; Ling, T.C. Primary recovery of lipase derived from Burkholderia cenocepacia strain ST8 and recycling of phase components in an aqueous two-phase system. Biochem. Eng. J. 2012, 60, 74-80. [CrossRef]

23. Show, P.L.; Tan, C.P.; Shamsul Anuar, M.; Ariff, A.; Yusof, Y.A.; Chen, S.K.; Ling, T.C. Extractive fermentation for improved production and recovery of lipase derived from Burkholderia cepacia using a thermoseparating polymer in aqueous two-phase systems. Bioresour. Technol. 2012, 116, 226-233. [CrossRef] [PubMed]

24. Chandrasekhar, J.; Sonika, G.; Madhusudhan, M.C.; Raghavarao, K.S.M.S. Differential partitioning of betacyanins and betaxanthins employing aqueous two phase extraction. J. Food Eng. 2015, 144, 156-163. [CrossRef]

25. Leong, H.Y.; Ooi, C.W.; Law, C.L.; Julkifle, A.L.; Show, P.L. Betacyanins extraction from Hylocereus polyrhizus using alcohol/salt-based liquid biphasic partitioning system and antioxidant activity evaluation. Sep. Sci. Technol. 2019, 54, 747-758. [CrossRef] 
26. Albertsson, P.A. Partition of Cell Particles and Macromolecules: Separation and Purification of Biomolecules, Cell Organelles, Membranes, and Cells in Aqueous Polymer Two-Phase Systems and Their Use in Biochemical Analysis and Biotechnology; Wiley: New York, NY, USA, 1986.

27. Hatti-Kaul, R. Aqueous Two-Phase Systems: Methods and Protocols; Humana Press: Totowa, NJ, USA, 2000.

28. Rosa, P.A.J.; Azevedo, A.M.; Sommerfeld, S.; Bäcker, W.; Aires-Barros, M.R. Aqueous two-phase extraction as a platform in the biomanufacturing industry: Economical and environmental sustainability. Biotechnol. Adv. 2011, 29, 559-567. [CrossRef] [PubMed]

29. Leong, H.Y.; Chang, Y.-K.; Ooi, C.W.; Law, C.L.; Julkifle, A.L.; Show, P.L. Liquid biphasic electric partitioning system as a novel integration process for betacyanins extraction from red-purple pitaya and antioxidant properties assessment. Front. Chem. 2019, 7, 201. [CrossRef]

30. Azmir, J.; Zaidul, I.S.M.; Rahman, M.M.; Sharif, K.M.; Mohamed, A.; Sahena, F.; Jahurul, M.H.A.; Ghafoor, K.; Norulaini, N.A.N.; Omar, A.K.M. Techniques for extraction of bioactive compounds from plant materials: A review. J. Food Eng. 2013, 117, 426-436. [CrossRef]

31. Wang, L.; Weller, C.L. Recent advances in extraction of nutraceuticals from plants. Trends Food Sci. Technol. 2006, 17, 300-312. [CrossRef]

32. Ooi, C.W.; Tey, B.T.; Hii, S.L.; Kamal, S.M.M.; Lan, J.C.-W.; Ariff, A.; Ling, T.C. Purification of lipase derived from Burkholderia pseudomallei with alcohol/salt-based aqueous two-phase systems. Process Biochem. 2009, 44, 1083-1087. [CrossRef]

33. González-Valdez, J.; Mayolo-Deloisa, K.; Rito-Palomares, M. Novel aspects and future trends in the use of aqueous two-phase systems as a bioengineering tool. J. Chem. Technol. Biotechnol. 2018, 93, 1836-1844. [CrossRef]

34. Yau, Y.K.; Ooi, C.W.; Ng, E.-P.; Lan, J.C.-W.; Ling, T.C.; Show, P.L. Current applications of different type of aqueous two-phase systems. Bioresour. Bioprocess. 2015, 2, 49. [CrossRef]

35. Leong, Y.K.; Chang, C.-K.; Arumugasamy, S.K.; Lan, J.C.-W.; Loh, H.-S.; Muhammad, D.; Show, P.L. Statistical design of experimental and bootstrap neural network modelling approach for thermoseparating aqueous two-phase extraction of polyhydroxyalkanoates. Polymers 2018, 10, 132. [CrossRef]

36. Benavides, J.; Rito-Palomares, M. Potential aqueous two-phase processes for the primary recovery of colored protein from microbial origin. Eng. Life Sci. 2005, 5, 259-266. [CrossRef]

37. Chang, Y.-K.; Show, P.-L.; Lan, J.C.-W.; Tsai, J.-C.; Huang, C.-R. Isolation of C-phycocyanin from Spirulina platensis microalga using Ionic liquid based aqueous two-phase system. Bioresour. Technol. 2018, 270, 320-327. [CrossRef] [PubMed]

38. Desai, R.K.; Streefland, M.; Wijffels, R.H.; Eppink, M.H. Extraction and stability of selected proteins in ionic liquid based aqueous two phase systems. Green Chem. 2014, 16, 2670-2679. [CrossRef]

39. Suarez Garcia, E.; Suarez Ruiz, C.A.; Tilaye, T.; Eppink, M.H.M.; Wijffels, R.H.; van den Berg, C. Fractionation of proteins and carbohydrates from crude microalgae extracts using an ionic liquid based-aqueous two phase system. Sep. Purif. Technol. 2018, 204, 56-65. [CrossRef]

40. Gómez-Loredo, A.; Benavides, J.; Rito-Palomares, M. Partition behavior of fucoxanthin in ethanol-potassium phosphate two-phase systems. J. Chem. Technol. Biotechnol. 2014, 89, 1637-1645. [CrossRef]

41. Najafabadi, H.A.; Pazuki, G.; Vossoughi, M. Experimental study and thermodynamic modeling for purification of extracted algal lipids using an organic/aqueous two-phase system. RSC Adv. 2015, 5, 1153-1160. [CrossRef]

42. Phong, W.N.; Le, C.F.; Show, P.L.; Chang, J.S.; Ling, T.C. Extractive disruption process integration using ultrasonication and an aqueous two-phase system for protein recovery from Chlorella sorokiniana. Eng. Life Sci. 2017, 17, 357-369. [CrossRef]

43. Chia, S.R.; Show, P.L.; Phang, S.-M.; Ling, T.C.; Ong, H.C. Sustainable approach in phlorotannin recovery from macroalgae. J. Biosci. Bioeng. 2018, 126, 220-225. [CrossRef] [PubMed]

44. Luo, X.; Smith, P.; Raston, C.; Zhang, W. Vortex fluidic device-intensified aqueous two phase extraction of C-phycocyanin from Spirulina maxima. ACS Sustain. Chem. Eng. 2016, 4, 3905-3911. [CrossRef]

45. Mittal, R.; Sharma, R.; Raghavarao, K. Aqueous two-phase extraction of R-Phycoerythrin from marine macro-algae, Gelidium pusillum. Bioresour. Technol. 2019, 280, 277-286. [CrossRef] [PubMed]

46. Bi, P.-Y.; Li, D.-Q.; Dong, H.-R. A novel technique for the separation and concentration of penicillin G from fermentation broth: Aqueous two-phase flotation. Sep. Purif. Technol. 2009, 69, 205-209. [CrossRef] 
47. Phong, W.N.; Show, P.L.; Teh, W.H.; Teh, T.X.; Lim, H.M.Y.; Nazri, N.S.b.; Tan, C.H.; Chang, J.-S.; Ling, T.C. Proteins recovery from wet microalgae using liquid biphasic flotation (LBF). Bioresour. Technol. 2017, 244, 1329-1336. [CrossRef] [PubMed]

48. Sankaran, R.; Show, P.L.; Lee, S.Y.; Yap, Y.J.; Ling, T.C. Integration process of fermentation and liquid biphasic flotation for lipase separation from Burkholderia cepacia. Bioresour. Technol. 2018, 250, 306-316. [CrossRef]

49. Sankaran, R.; Show, P.L.; Yap, Y.J.; Tao, Y.; Ling, T.C.; Tomohisa, K. Green technology of liquid biphasic flotation for enzyme recovery utilizing recycling surfactant and sorbitol. Clean Technol. Environ. Policy 2018, 20, 2001-2012. [CrossRef]

50. Sankaran, R.; Manickam, S.; Yap, Y.J.; Ling, T.C.; Chang, J.-S.; Show, P.L. Extraction of proteins from microalgae using integrated method of sugaring-out assisted liquid biphasic flotation (LBF) and ultrasound. Ultrason. Sonochem. 2018, 48, 231-239. [CrossRef]

51. Sankaran, R.; Show, P.L.; Cheng, Y.-S.; Tao, Y.; Ao, X.; Nguyen, T.D.P.; Van Quyen, D. Integration process for protein extraction from microalgae using liquid biphasic electric flotation (LBEF) system. Mol. Biotechnol. 2018, 60, 749-761. [CrossRef]

52. Leong, H.Y.; Ooi, C.W.; Law, C.L.; Julkifle, A.L.; Ling, T.C.; Show, P.L. Application of liquid biphasic flotation for betacyanins extraction from peel and flesh of Hylocereus polyrhizus and antioxidant activity evaluation. Sep. Purif. Technol. 2018, 201, 156-166. [CrossRef]

53. Leong, H.Y.; Ooi, C.W.; Law, C.L.; Julkifle, A.L.; Katsuda, T.; Show, P.L. Integration process for betacyanins extraction from peel and flesh of Hylocereus polyrhizus using liquid biphasic electric flotation system and antioxidant activity evaluation. Sep. Purif. Technol. 2019, 209, 193-201. [CrossRef]

54. Chia, S.R.; Chew, K.W.; Show, P.L.; Manickam, S.; Ling, T.C.; Tao, Y. Isolation of protein from Chlorella sorokiniana CY1 using liquid biphasic flotation assisted with sonication through sugaring-out effect. J. Oceanol. Limnol. 2019. [CrossRef]

55. Chew, K.W.; Chia, S.R.; Krishnamoorthy, R.; Tao, Y.; Chu, D.-T.; Show, P.L. Liquid biphasic flotation for the purification of C-phycocyanin from Spirulina platensis microalga. Bioresour. Technol. 2019, 288, 121519. [CrossRef] [PubMed]

56. Sebba, F. Concentration by ion flotation. Nature 1959, 184, 1062-1063. [CrossRef]

57. Sebba, F. Ion Flotation; Elsevier: New York, NY, USA, 1962.

58. Show, P.L.; Tan, C.P.; Anuar, M.S.; Ariff, A.; Yusof, Y.A.; Chen, S.K.; Ling, T.C. Direct recovery of lipase derived from Burkholderia cepacia in recycling aqueous two-phase flotation. Sep. Purif. Technol. 2011, 80, 577-584. [CrossRef]

59. Show, P.L.; Ooi, C.W.; Anuar, M.S.; Ariff, A.; Yusof, Y.A.; Chen, S.K.; Annuar, M.S.M.; Ling, T.C. Recovery of lipase derived from Burkholderia cenocepacia ST8 using sustainable aqueous two-phase flotation composed of recycling hydrophilic organic solvent and inorganic salt. Sep. Purif. Technol. 2013, 110, 112-118. [CrossRef]

60. Martínez, J.M.; Delso, C.; Álvarez, I.; Raso, J. Pulsed electric field permeabilization and extraction of phycoerythrin from Porphyridium cruentum. Algal Res. 2019, 37, 51-56. [CrossRef]

61. Yellapu, S.K.; Kaur, R.; Kumar, L.R.; Tiwari, B.; Zhang, X.; Tyagi, R.D. Recent developments of downstream processing for microbial lipids and conversion to biodiesel. Bioresour. Technol. 2018, 256, 515-528. [CrossRef]

62. Günerken, E.; D’Hondt, E.; Eppink, M.H.M.; Garcia-Gonzalez, L.; Elst, K.; Wijffels, R.H. Cell disruption for microalgae biorefineries. Biotechnol. Adv. 2015, 33, 243-260. [CrossRef]

63. Christenson, L.; Sims, R. Production and harvesting of microalgae for wastewater treatment, biofuels, and bioproducts. Biotechnol. Adv. 2011, 29, 686-702. [CrossRef]

64. Odjadjare, E.C.; Mutanda, T.; Olaniran, A.O. Potential biotechnological application of microalgae: A critical review. Crit. Rev. Biotechnol. 2017, 37, 37-52. [CrossRef] [PubMed]

65. Spolaore, P.; Joannis-Cassan, C.; Duran, E.; Isambert, A. Commercial applications of microalgae. J. Biosci. Bioeng. 2006, 101, 87-96. [CrossRef] [PubMed]

(C) 2019 by the authors. Licensee MDPI, Basel, Switzerland. This article is an open access article distributed under the terms and conditions of the Creative Commons Attribution (CC BY) license (http://creativecommons.org/licenses/by/4.0/). 